Tadesse, A., Zakaria, D., Zoubeir L. (2018). "Characterization of Waste in Ethiopian Building Construction Projects." In: Proc. $26^{\text {th }}$ Annual Conference of the International. Group for Lean Construction (IGLC), González, V.A. (ed.), Chennai, India, pp. 797-806. DOI: doi.org/10.24928/2018/0505 Available at: www.iglc.net

\title{
CHARACTERIZATION OF WASTE IN ETHIOPIAN BUILDING CONSTRUCTION PROJECTS
}

\author{
Tadesse Ayalew ${ }^{1}$, Zakaria Dakhli $^{2}$, Zoubeir Lafhaj ${ }^{3}$
}

\begin{abstract}
According to the February 2017 Mckinsey Global Institute report, construction industry is one of the largest sectors in the world economy with $\$ 10$ trillion spending, $13 \%$ of GDP contribution and 7\% employment opportunity annually. However, the sector laborproductivity for the past two decades couldn't exceed $1 \%$ a year while the total world economy and the manufacturing sector has been grown by 2.8 and $3.6 \%$ respectively. As a result of this, the industry loss a value of $\$ 1.6$ trillion a year that would meet about half of the world's annual infrastructure needs or boost global GDP by $2 \%$.

According to this report, Ethiopia is the last in the list of countries with poor productivity. Considering the above fact, this study assess building construction projects in Ethiopia with respect to the common types of waste in order to identify the most important waste in Ethiopian building construction projects.

Accordingly the study confirmed that close to $40 \%$ of the project time is wasted in performing non value adding activities due to over production, over processing, Transport, motion and waiting related wastes.
\end{abstract}

\section{KEYWORDS}

Ethiopia, building projects, lean construction, process, waste

\section{INTRODUCTION}

Construction industry is one of the largest sectors in the world economy with $\$ 10$ trillion spending, $13 \%$ of GDP contribution and 7\% employee annually (Barbosa et al., 2017), However, the industry has been criticized for its underperformance for many years. For example, the sector labor-productivity for the past two decades couldn't exceed 1\% a year while the total world economy and the manufacturing sector has been grown 2.8 and $3.6 \%$ respectively(Barbosa et al., 2017). As a result, the industry is facing a value loss of

1 PhD Student, Centrale Lille, Laboratory de Mechanique de Lille, CNRS UMR 8107,Cite Scientific, Villeneuve d'Ascq, 59651 Cedex, France,+33751099251,tadesse.ayalew@phd.centralelille.fr

2 Research Engineer, Centrale Lille, Laboratory de Mechanique de Lille, CNRS UMR 8107,Cite Scientific, Villeneuve d'Ascq, 59651 Cedex, France,zakaria.dakhli@gmail.com.

3 Professor of Civil Engineering, Centrale Lille, Laboratory de Mechanique de Lille, CNRS UMR 8107,Cite Scientific, Villeneuve d'Ascq, 59651 Cedex, France, zoubeir.lafhaj@ec-lille.fr 
\$1.6 trillion a year, which would meet about half of the world's annual infrastructure, needs or boost global GDP by $2 \%$.

An assessment on 25 countries including Ethiopia in this regard indicates that only $25 \%$ of construction firms matched the productivity growth achieved by the overall economies of their respective countries. The report also pointed out that, Ethiopia is the most poorly performing country in this regard(See Fig 1, below). The result confirms the finding of Ethiopian economics association, that reported construction output per employee in Ethiopia is only US \$994.9, which is far behind corresponding low income countries average of US $\$ 8507$ (On \& Ethiopian, 2005).

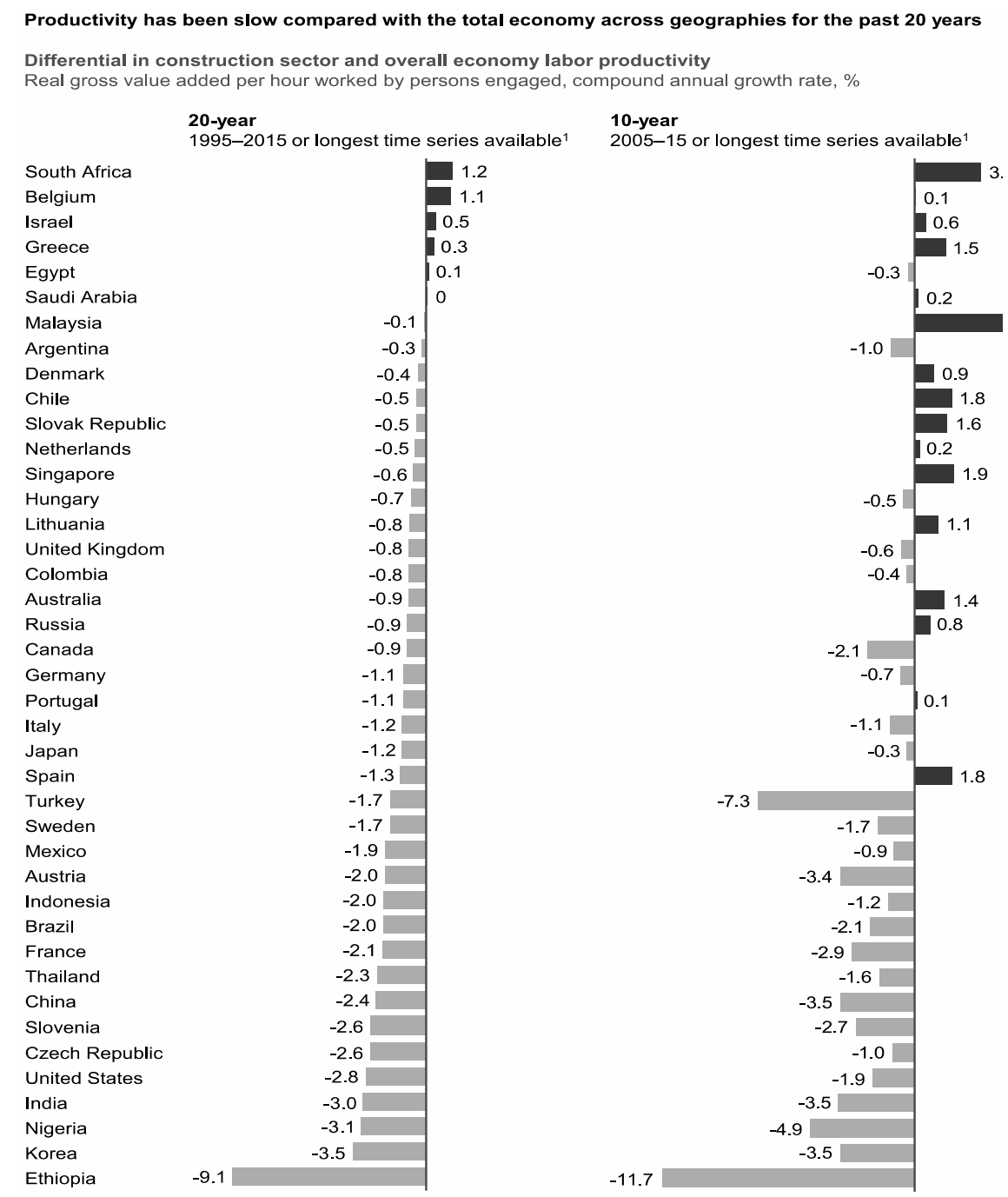

Figure 1: Differential Construction Sector and Overall Economy Labor Productivity (Figure 10, in Barbosa et al., 2017)

It is therefore imperative to identify the characteristics of this waste that causes such poor performance. However there is no previous study on waste in Ethiopian construction 
industry except an assessment on professional awareness on lean construction and related concepts by (Ayalew, Dakhli, \& Lafhaj, 2016). According to this study $48 \%$ of professionals are aware of the lean concept but lean is not yet practiced in Ethiopian construction industry.

This study therefore tries to characterize the seven common types of wastes in Ethiopian construction industry using a local survey in order to buy professionals concern on the subject of lean construction in general and that of waste in particular.

\section{WASTE IN CONSTRUCTION PROJECT}

Construction industry is a diverse sector of the national economy, which involves a wide range of scarce resources for a given country; therefore productivity of construction industry concerns not only the industry itself, but also other industries, which depends on its performance. This is particularly important for developing countries like Ethiopia which involves massive construction activities with these days(Ofori, 2006). Due to this, productivity and waste are considered to be central issues for improvements(Forsberg \& Saukkoriipi, 2007). This section therefore will explore different literatures to identify various categories of wastes as a base for assessment.

\section{DEFINITION OF WASTE}

Construction professionals tend to conceptualize "waste" as physical construction waste rather than a more generic conception of the term that include both the incidence of material losses as well as the execution of unnecessary work(Ramaswamy \& Kalidindi, 2008). This misunderstanding is more significant in developing courtiers like Ethiopia with very little knowledge on the concept of lean construction (Ayalew, Dakhli, \& Lafhaj, 2016). It is therefore essential to understand a broader view of waste that includes not only material waste, but also waste related to resources such as labor and equipment. With this understanding (L. Koskela, 1992) defines waste as any inefficiency that results in the use of equipment, materials, labor, or capital in larger quantities than those considered as necessary in the production processes. In this context value can be understood as the fulfillment of customer requirements. Similarly, in the lean production paradigm, the concept of waste is directly associated with the use of resources that do not add value to the final product(Ramaswamy \& Kalidindi, 2008)(Howell \& Ballard, 1994)(Alarcón, Diethelm, Rojo, \& Calderón, 2008)

Therefore, waste should be defined as any losses produced by activities that generate direct or indirect costs but do not add any value to the product from the point of view of the customer (client).

\section{CLASSIFICATION OF WASTE}

Waste can be classified as unavoidable waste (or natural waste), in which the investment needed to its reduction is higher than the economy produced, and avoidable waste, when the cost of waste is significantly higher than the cost to prevent it(Formoso \& Hirota, 1999). Similarly(Serpell, Venturi, \& Contreras, 1995)categorized wastes as controllable and non-controllable where controllable wastes are wastes related to flow, conversion 
and management activities where as non-controllable waste include waste due to failure in external flow and environmental causes. Fig. 2 below illustrates categories of wastes by(Serpell et al., 1995).

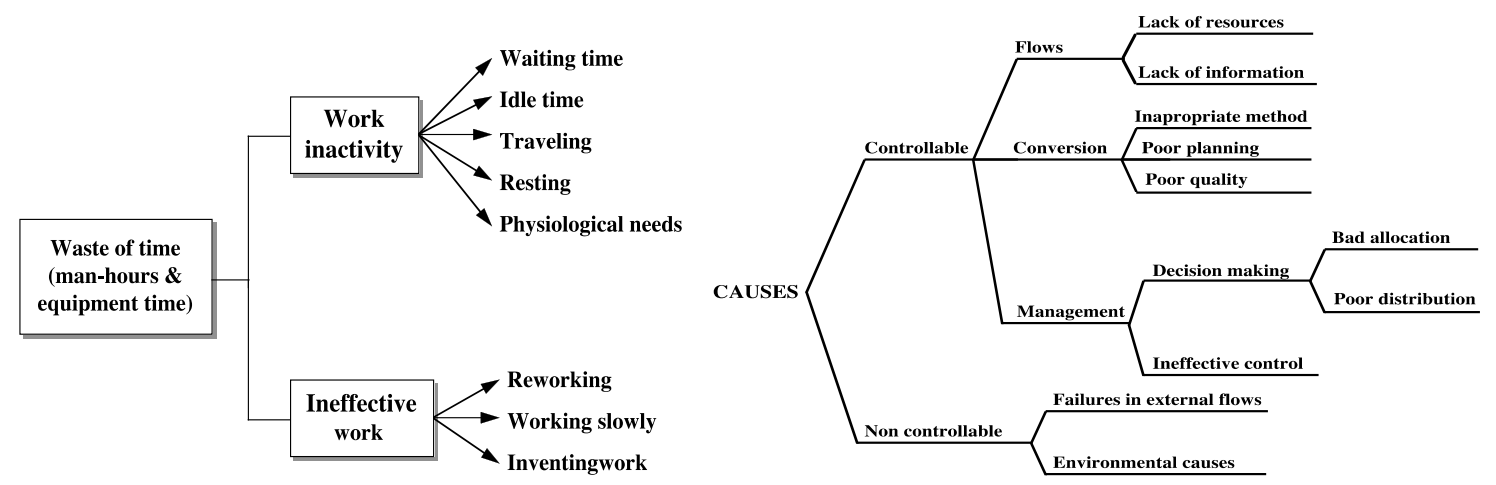

Figure 2: Category of Waste and Their Causes ( Figure 3, inSerpell et al., 1995)

(Ramaswamy \& Kalidindi, 2008) on the other hand classified waste into the following four groups. These include materials, quality, labor and equipment.

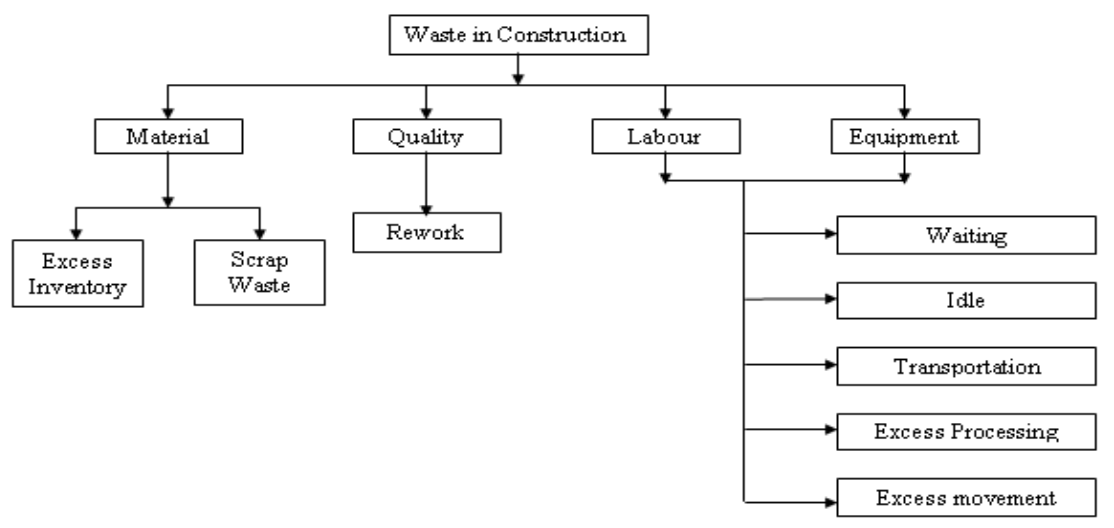

Figure 3: Classification of Waste (Figure...inRamaswamy \& Kalidindi, 2008)

Waste can also be classified according to its origin, i.e. the stage that the main root cause is related to. Classifying construction waste according to its origin enables managers to understand the different forms of waste, why they occur and how to act in order to avoid them. In this regard (Formoso \& Hirota, 1999) customized the seven types of waste identified in the Toyota production system from construction perspective. This research also basis its assessment on this base. Table1 below summarizes the seven wastes from (Formoso \& Hirota, 1999) and their description; 
Table 1: Types of Waste and their description

\begin{tabular}{|c|c|}
\hline Categoryof Waste & Description \\
\hline Overproduction & $\begin{array}{l}\text { Production of a quantity greater than required or earlier than necessary, } \\
\text { which may cause waste of materials, man-hours or equipment usage. }\end{array}$ \\
\hline Waiting time: & $\begin{array}{l}\text { This kind of waste related to idle time caused by lack of synchronization } \\
\text { and leveling of material flows, and pace of work by different crew or } \\
\text { equipment. }\end{array}$ \\
\hline Transportation: & $\begin{array}{l}\text { Concerned with the internal movement of materials on site. It is usually } \\
\text { related to poor layout, and the lack of planning of material flows. Its main } \\
\text { consequences are: waste of man hours, waste of energy and the } \\
\text { possibility of material waste during transportation. }\end{array}$ \\
\hline Processing: & $\begin{array}{l}\text { This one is related to the nature of the processing (conversion) activity, } \\
\text { which could only be avoided by changing the construction technology. }\end{array}$ \\
\hline Inventories: & $\begin{array}{l}\text { This is due to excessive or unnecessary inventories, which lead to } \\
\text { material waste (by deterioration, losses due to inadequate stock } \\
\text { conditions on site, robbery, vandalism), and monetary losses due to } \\
\text { capital tied up. It might be a result of lack of resource planning or } \\
\text { uncertainty on the estimation of quantities. }\end{array}$ \\
\hline Movement: & $\begin{array}{l}\text { Concerned with unnecessary or inefficient movements made by workers } \\
\text { during their job. This might be caused by inadequate equipment, } \\
\text { ineffective work methods, or poor arrangement of the working place. }\end{array}$ \\
\hline $\begin{array}{l}\text { Production of } \\
\text { defective products: }\end{array}$ & $\begin{array}{l}\text { It occurs when the final or intermediate product does not fit the quality } \\
\text { specifications. It can be caused by a wide range of reasons: poor design } \\
\text { and specification, lack of planning and control, poor qualification of the } \\
\text { team work, lack of integration between design and production, etc. }\end{array}$ \\
\hline
\end{tabular}

In addition to the above waste category identified earlier, (Lauri Koskela, 2004) and (Macomber \& Howell, 2004) recently identified "Making do" and "Underutilization of human potential" as a common types of wastes in construction. Although they are not included in the survey since the researcher were not well aware of these category of wastes during data collection, these category of wastes are also a major concern for construction industry in developing countries in general and that of Ethiopian construction industry in particular.

\section{METHODOLOGY}

The study approach involves both literature search and the use of structured questionnaire, which was considered to be more appropriate tool to reach the population of the study with limited time and from a distance at a time. The literature review was conducted to extract variables for the assessment and to have a conceptual bases on the subject.

According to Ministry of housing and construction, currently there are 138 Category I and 44 Category I Consultants in the capital. Out of which 55 Contractors and 22 Consulting firms were considered as a representative sample for this study. Accordingly 
the designed questionnaire were distributed to 83 professionals selected through stratified random sampling from 55 construction companies, 22 consulting firms and 6 clients which are actively involved on building construction projects in the capital. Out of the 83 questionnaires distributed, 68 were received completed and found suitable for analysis, representing a responses rate of $81.93 \%$.

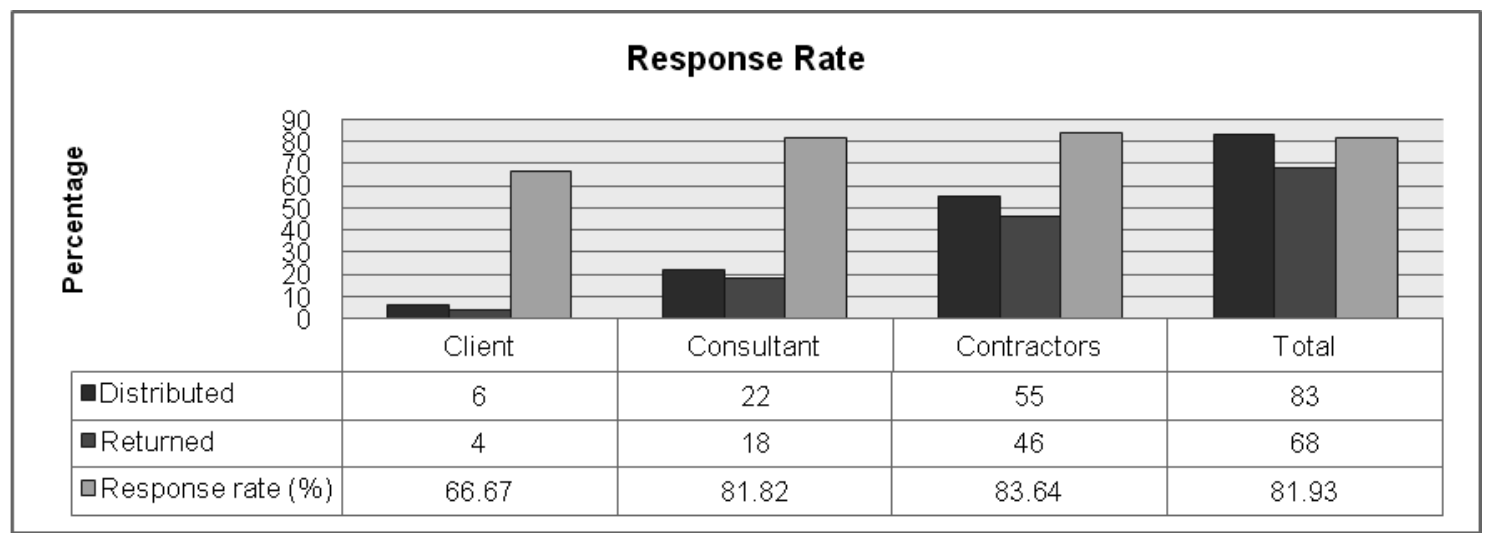

Figure 4: Respondent Response Rate

The data obtained from the survey was analyzed using mean score in order to rank the major types of waste in Ethiopian building construction projects. The output is then presented using tables and graphs for further interpretation and discussion.

\section{RESULT AND DISCUSSION}

As shown in Fig. 5 below, $9 \%$ of the respondents were General \& Deputy General mangers, 12\% Project Coordinators, 18\% Project Managers, 19\% Site Engineers, 10\% Office Engineers, 7\% Resident Engineers, 10\% Supervisors and 6\% others.

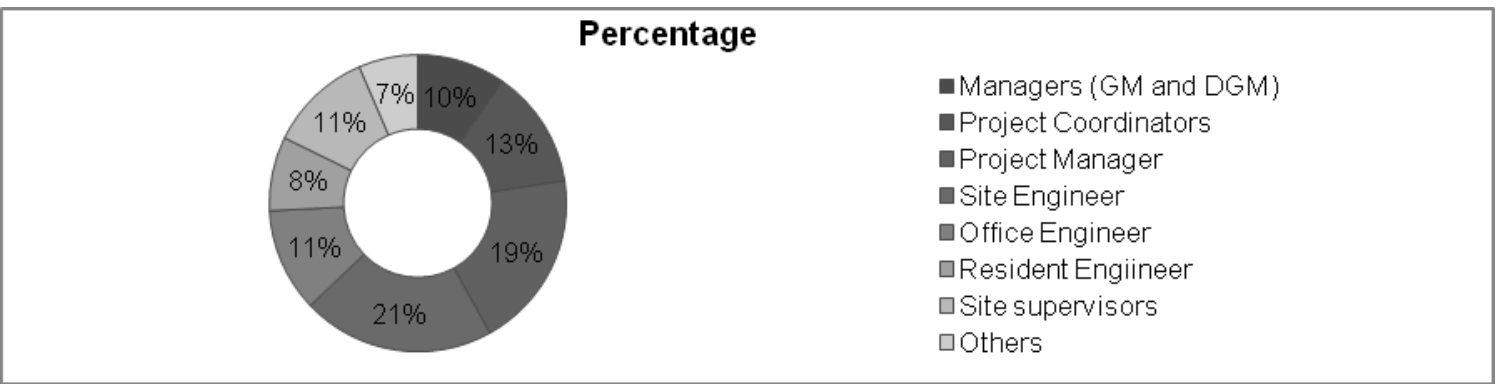

Figure 5: Respondent Profile Based on Their Position

This indicates that the respondent are raging from the top management who is responsible for strategic and tactical planning to site engineers who are mainly responsible to the day to day operational activities on construction site. In terms of experience, about $65 \%$ of the respondent has more than 6years' professional experiences, which is sufficient to understand the construction processes and related wastes. 


\section{EXTENT OF TIMEWASTE}

Following their profile identification, respondent were requested their opinion on the existence and extent of waste in Ethiopian construction industry. In this regard $100 \%$ of the respondent agreed that waste is one of major problem that challenges Ethiopian construction industry. Regarding its extent, more than $(60 \%)$ of the respondent believes that the extent of wasted time in Ethiopian context is about $30-40 \%$. The finding from site observation on randomly selected work item show ever confirmed that more than $50 \%$ of the working hour is wasted in performing non-value adding activities (See table 2 and 3, below).

Table 2: Site Observation on Time Waste for Concrete Work

\begin{tabular}{|c|c|c|c|c|c|c|c|c|c|}
\hline \multirow[b]{2}{*}{$\begin{array}{c}\text { Item } \\
\text { No }\end{array}$} & \multirow[b]{2}{*}{ Category } & \multicolumn{8}{|c|}{ Productive time out of the 8 working hours in a day } \\
\hline & & $\begin{array}{c}\text { Day } \\
1\end{array}$ & $\begin{array}{c}\text { Day } \\
2\end{array}$ & $\begin{array}{c}\text { Day } \\
3\end{array}$ & $\begin{array}{c}\text { Day } \\
4\end{array}$ & $\begin{array}{c}\text { Day } \\
5\end{array}$ & $\begin{array}{c}\text { Day } \\
6\end{array}$ & Average & $\begin{array}{c}\text { Productive } \\
\text { Time (\%) }\end{array}$ \\
\hline 1 & Mason & 3,16 & 3,56 & 3,41 & 2,16 & 2,46 & 3,24 & 3,00 & 37,48 \\
\hline 2 & Loader Operator & 3,42 & 0 & 4,52 & 0 & 3,42 & 0 & 3,79 & 47,33 \\
\hline 3 & Crane Operator & 4,23 & 4,43 & 3,53 & 4,07 & 4,03 & 3,47 & 3,96 & 49,50 \\
\hline 4 & Mixer Operator & 5,01 & 4,51 & 4,05 & 4,19 & 4,51 & 3,19 & 4,24 & 53,04 \\
\hline 5 & Daily laborer & 4,19 & 4,39 & 4,09 & 4,07 & 3,40 & 3,42 & 3,93 & 49,08 \\
\hline
\end{tabular}

Table 3: Site Observation on Time Waste for Hollow Concrete Block Work

\begin{tabular}{|c|c|c|c|c|c|c|c|c|c|}
\hline \multirow[b]{2}{*}{$\begin{array}{c}\text { Item } \\
\text { No }\end{array}$} & \multirow[b]{2}{*}{ Category } & \multicolumn{8}{|c|}{ Productive time out of the 8 working hours in a day } \\
\hline & & $\begin{array}{c}\text { Day } \\
1\end{array}$ & $\begin{array}{c}\text { Day } \\
2\end{array}$ & $\begin{array}{c}\text { Day } \\
3\end{array}$ & $\begin{array}{c}\text { Day } \\
4\end{array}$ & $\begin{array}{c}\text { Day } \\
5\end{array}$ & $\begin{array}{c}\text { Day } \\
6\end{array}$ & Average & $\begin{array}{c}\text { Productive } \\
\text { Time (\%) }\end{array}$ \\
\hline 1 & Mason & 3,34 & 3,27 & 2,57 & $\begin{array}{c}3,5 \\
7\end{array}$ & 3,25 & 3,42 & 3,24 & 40,46 \\
\hline 2 & Winch Operator & 3,47 & 4,47 & 4,3 & 2,2 & 3,3 & 4,55 & 3,72 & 46,44 \\
\hline 3 & Daily laborer & 3,55 & 4,3 & 4,47 & $\begin{array}{c}4,1 \\
2 \\
\end{array}$ & 3,45 & 4,25 & 4,02 & 50,29 \\
\hline
\end{tabular}

The finding some how agreed with the finding of other researchers in this regard. For example (Serpell et al., 1995) analyzing 17 building projects in Chile reported that a minimum and maximum value of $35 \%$ and $55 \%$. In Sweden the amount of waste was reported around 30-35\% (Forsberg \& Saukkoriipi, 2007), (Lauri Koskela, 2000) on his part reported that the average distribution of working time used in value-adding activities are in the range of $30 \%$ to $40 \%$. This means about $60-70 \%$ of the time is lost in performing non-value adding activities.

\section{THE MOST INFLUENTIAL TYPE OF WASTE IN ETHIOPIAN CONTEXT}

In order to rank the seven types of waste identified from literatures, professionals working in the sector were requested to rate each type of wastes based on their frequency 
of occurrence using a 4-point scale. The study identify that over production waste (3.08), over processing waste (3;03) and Transport waste (3.03) are the most dominating type of wastes in Ethiopian building construction projects.

According to (Formoso \& Hirota, 1999), over production waste occurs due to production of quantity greater than required or earlier than necessary, which leads to waste of materials, man-hours or equipment usage. This kind of waste is common in most building construction projects in Ethiopia. As an example over production of hollow concrete blocks, which is usually left over on construction site after project completion or damaged during transpiration to another sites. Similarly ordering greater quantities of materials such reinforcement and floor, pipes, electrical cables\& tiles are also a major problem in Ethiopian context. Overproduction of mortar that cannot be used on time is also significant problem on many construction sites.

This type of waste also contributes for "Making do" and "Underutilization of human potential" related wastes which are identified by (Lauri Koskela, 2004) and (Macomber \& Howell, 2004) respectively.

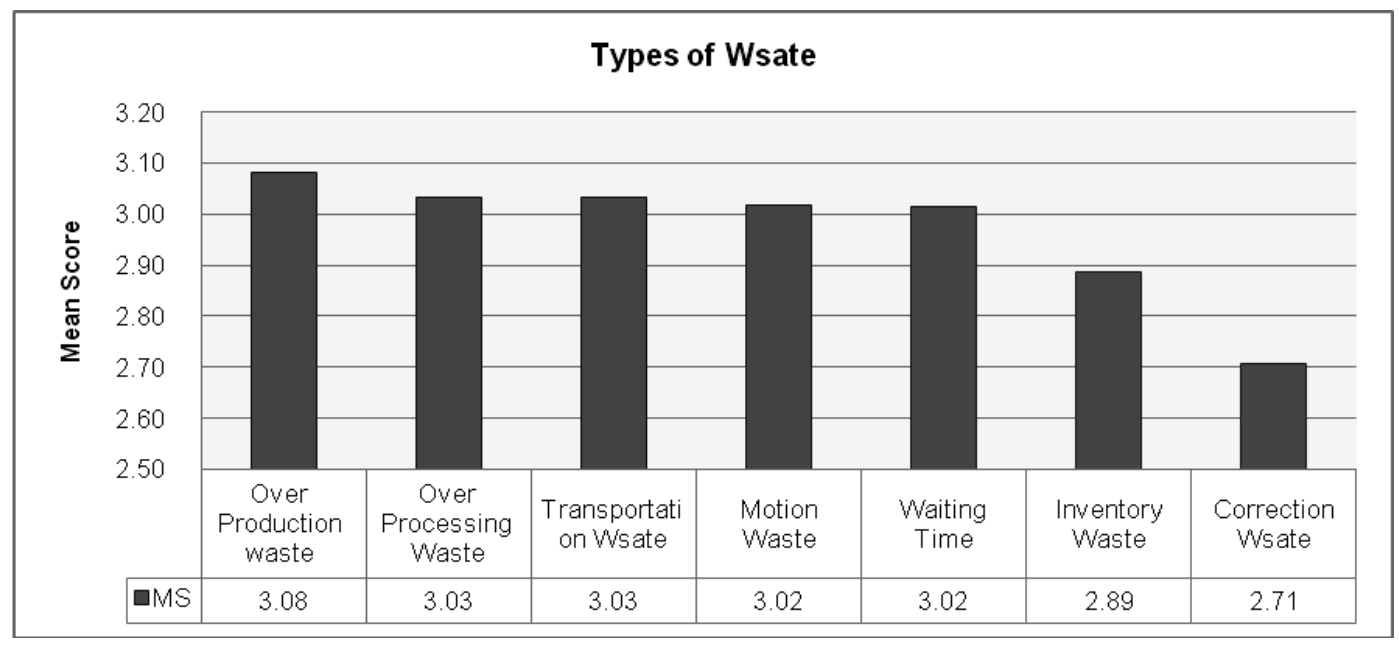

Figure 6: Types of Waste and their Order Priority

Internal movement of materials within construction sites, which is usually related to poor site layout, and lack of planning of material flow is also another common problem in Ethiopian context. As pointed out by(Formoso \& Hirota, 1999) the consequences of such type of waste are waste of man hours, waste of energy and the possibility of material waste during transportation. Developing a site layout plan for construction projects is not a common practice in most construction sites in Ethiopia, as result moving materials repeatedly from one place to other (which is considered as non value adding activity) is also significant problem.

Over processing waste is a waste that could be avoided by changing the construction technology. This kind of waste is obvious to be one of the critical types of waste in developing countries, which are still using traditional construction technology in their business. Some examples of waste related to over processing in the Ethiopian context include, concrete production on construction sites during batching, mixing and 
transporting of concrete, which is common almost in all construction projects. A percentage of mortar wasted while plastering of ceiling is also another common problem related to lack of advanced methods. In the same fashion a percentage of concert blocks cut to close small size of openings and stone wasted during dressing are some examples in construction sites. As one of the developing country in Africa, over processing is typical problem in the day-to-day practice of construction within Ethiopian construction industry.

As shown in Fig 6 above motion waste and waiting time are also significant types of waste with equal level of importance (3.02). The first one is mainly caused by lack of synchronization and leveling of material flows, and piece of work by different crew or equipment where as the second one concerned with unnecessary or inefficient movements made by workers during their job which may be caused due to inadequate equipment, ineffective work methods, or poor arrangement of the working place.

\section{CONCLUSION}

The study identifies seven types of wastes from literatures and conducted a survey on the extent of waste and their frequency of occurrence in Ethiopian building construction projects. Accordingly over production waste (3.08), over processing waste $(3 ; 03)$, Transport waste (3.03), waiting time (3.02)and motion wastes (3.02)are found to be the most dominating wastes in Ethiopian building construction projects.

Considering this study as a base, the research will further identify the root causes of these wastes and their consequence in Ethiopian building construction projects to bring academics and practitioners concern on waste in particular and lean construction in general as an intervention for overall improvement of Ethiopian construction industry.

\section{ACKNOLDGEEMENT}

The researchers would like to thank all professionals involved in the survey and undergraduate students for their support in collecting some of the data used in this paper.

\section{REFERENCES}

Alarcón, L., Diethelm, S., Rojo, O., \& Calderón, R. (2008). Assessing the impacts of implementing lean construction Evaluando los impactos de la implementación de lean construction. SciELO Chile, 23(October), 26-33. Retrieved from http://www.scielo.cl/pdf/ric/v23n1/art03.pdf

Ayalew, T., Dakhli, Z., \& Lafhaj, Z. (2016). The Future of Lean Construction in Ethiopian Construction Industry, 5(02), 107-113.

Barbosa, F., Woetzel, J., Mischke, J., Ribeirinho, M. J., Sridhar, M., Parsons, M., ... Brown, S. (2017). Reinventing Construction: A Route To Higher Productivity, (February), 168. Retrieved from http://www.mckinsey.com/industries/capitalprojects-and-infrastructure/our-insights/reinventing-construction-through-aproductivity-revolution

Formoso, C. T., \& Hirota, E. H. (1999). Method of Waste Control, 325-334. 
Forsberg, A., \& Saukkoriipi, L. (2007). Measurement of Wsate and Productivity in Relation to Lean, 46(July), 67-76.

Howell, G., \& Ballard, G. (1994). Implementing lean construction: reducing inflow variation. Proceedings of the 2nd Annual Meeting of the International Group for Lean Construction, 93-100.

Koskela, L. (1992). Application of the new production philosophy to construction. Tech. Report, 37-62.

Koskela, L. (2000). An Exploration towards a Production Theory and its Application to Construction. Construction, 298.

Koskela, L. (2004). Making-do - The eighth category of waste. Proceedings of the 12th Annual Conference of the International Group for Lean Construction.

Macomber, H., \& Howell, G. (2004). Two great wastes in organizations. IGLC, Denmark, 1-9. Retrieved from http://tranzit.planet.ee/TTU MATERIALS/Ehitus JUHTIMINE/Referaat/13105_079-howell-macomber-final[1].pdf

Ofori, G. (2006). Revaluing Construction in Developing Countries: A Research Agenda. Journal of Construction in Developing Countries, 11(d), 1-16.

On, R., \& Ethiopian, T. H. E. (2005). Report of The Ethiopian Volume V 2005 / 06 Unemployment Challenges and Prospects Ethiopian Economic Association (Vol. V).

Ramaswamy, K. P., \& Kalidindi, S. N. (2008). Wsate in Indian Construction, 3-14.

Serpell, A., Venturi, A., \& Contreras, J. (1995). Characterization of waste in building construction projects. 3rd Annual Conference Internacional Group for Lean Construction, 1-23. https://doi.org/10.13140/2139628487 